\title{
Pembuatan Penakar Hujan Berbiaya Rendah Menggunakan Sensor Beban Berbasis Arduino Uno
}

\author{
Agusta Kurniawan ${ }^{1}$, Indah Mulia ${ }^{2}$, Sabella Nisa Adelia Rifai ${ }^{3}$, Sigit Purwandika ${ }^{4}$ \\ ${ }^{1}$ Stasiun Klimatologi Kelas IV Sleman, Badan Meteorologi Klimatologi dan Geofisika \\ (BMKG), Jl. Kabupaten KM. 5.5, Duwet, Sendangadi, Mlati, Kabupaten Sleman, Daerah \\ Istimewa Yogyakarta, Indonesia, 55285. \\ 1agusta6872@gmail.com \\ 2,3,4Program Studi Fisika, Jurusan Pendidikan Fisika, Fakultas Matematika Dan Ilmu \\ Pengetahuan Alam, Univeristas Negeri Yogyakarta. Jalan Colombo No. 1, Karangmalang, \\ Yogyakarta 55281, Indonesia. \\ 2indahmuliaa859@gmail.com, ${ }^{3}$ sabellanisa@gmail.com, ${ }^{4}$ sigitpurwandika@gmail.com
}

\begin{abstract}
Abstrak
Telah dibuat penakar hujan dengan sistem timbangan berbasis Arduino Uno. Sensor beban (load cell) akan mengukur massa air hujan menggunakan prinsip jembatan wheatstone. Nilai massa air hujan akhirnya akan dikonversi menjadi nilai curah hujan. Pembuatan alat dilakukan dengan menghubungkan sensor beban dengan konverter ADC HX711 yang juga bekerja sebagai penguat, Arduino Uno untuk mengubah data yang dihasilkan sensor ke data curah hujan, dan MATLAB untuk menampilkan hubungan antara waktu dan curah hujan. Tahapan pembuatan penakar hujan terbagi menjadi perancangan bagian elektronika, pembuatan program pada Arduino Uno, pembuatan program pada MATLAB dan terakhir mengamati keluaran data curah hujan. Hasil pengujian menunjukkan masih ada perbedaan massa antara keluaran alat ukur penakar hujan dengan massa di neraca digital pada berbagai variasi curah hujan dari $1 \mathrm{~mm}$ hingga $100 \mathrm{~mm}$. Massa air hujan terbaca sama antara neraca digital dan respon sensor load cell saat curah hujan $54 \mathrm{~mm}$, yaitu saat menunjukkan massa 105 gram. Saat curah hujan di bawah $54 \mathrm{~mm}$, massa neraca digital lebih besar daripada massa respon pada sensor load cell, kebalikannya saat curah hujan di atas 54 $\mathrm{mm}$, massa neraca digital lebih kecil daripada massa respon pada sensor load cell.
\end{abstract}

Kata kunci: Sensor beban, Arduino Uno, Matlab, konverter ADC HX711, jembatan wheatstone

\begin{abstract}
A rain gauge was made by means of an Arduino Uno-based weighing scale. A load cell measured the mass of rainfall using the principle of Wheatstone bridge. The mass of rainfall were then converted to the rainfall intensity. The realization of this system was done by connecting the load cell to the ADC converter HX711 to amplify the carried signals. An Arduino Uno was utilized to convert the obtained data to rainfall intensity. A MATLAB software was employed to display the relationship between the rainfall intensity and time. The rain gauge realization was composed by several steps including electronics design, Arduino Uno and MATLAB programming, and lastly rainfall data observations. The results showed that there were discrepancy of rainfall mass between that obtained by this rain
\end{abstract}


gauge and digital scale under variation of rainfall intensity from $1 \mathrm{~mm}$ to $100 \mathrm{~mm}$. The measured rainfall mass by this rain gauge and digital scale were identical at rainfall intensity of $54 \mathrm{~mm}$, which corresponds to mass of 105 gram. When the rainfall intensity is less than $54 \mathrm{~mm}$, the digital scale yielded higher mass than that obtained by the rain gauge. On the contrary, when the rainfall intensity is greater than $54 \mathrm{~mm}$, the digital scale gave lower mass than that obtained by the rain gauge.

Keywords: Load cell, Arduino Uno, Matlab, ADC Converter HX711, wheatstone bridge

\section{Pendahuluan}

Pengetahuan yang tepat tentang curah hujan dan distribusi spasialnya penting untuk beberapa tujuan hidrologi dan pertanian, seperti pengelolaan air minum, perencanaan irigasi atau pemodelan hidrologi [1]. Air di daerah ekuator pada umumnya dipenuhi dari curah hujan pada musim hujan dan saluran irigasi pada musim kemarau. Agar pemanfaatannya air hujan dapat Iebih efektif maka perlu pengukuran yang lebih efektif pula [2]. Presipitasi didefinisikan sebagai air yang jatuh dalam fase cair atau padat ke tanah, termasuk curah hujan, salju atau embun. Presipitasi adalah jumlah air yang mencapai permukaan udara-tanah dalam interval waktu tertentu. Ada tiga jenis alat pengukur hujan utama dapat dibedakan: (i) penakar hujan manual, (ii) penakar hujan tipping bucket dan (iii) penakar hujan pengukur massa [3]. Prinsip operasi alat pengukur ini dapat ditemukan di WMO [3].

Untuk tujuan meteorologi, pengukur biasanya dipasang pada ketinggian tertentu $(0,5$ $\mathrm{m}$ hingga $1,5 \mathrm{~m}$ ) di atas tanah [3]. Namun untuk tujuan hidrologi diperlukan pengetahuan pasti tentang presipitasi secara langsung di permukaan udara-tanah. Karena ukuran, bentuk dan tinggi pemasangan penakar hujan berpotensi mengalami kesalahan acak dan sistematis. Kesalahan sistematis yang paling berpengaruh adalah deformasi bidang angin di atas penakar hujan. Kesalahan ini meningkat seiring ketinggian. Kesalahan sistematis lainnya terjadi karena adanya tetesan/rembesan ke dinding internal wadah, penguapan atau percikan. Kesalahan sistematik dapat dikurangi dengan faktor-faktor koreksi variabel yang menghitung jumlah meteorologis seperti kecepatan angin, suhu atau jenis presipitasi dan intensitas. Namun, oleh karena itu data tersebut harus tersedia di dekat alat pengukur hujan. Kesalahan acak terutama disebabkan oleh ukuran relatif kecil dari pengukur tipikal (permukaan $200 \mathrm{~cm}^{2}$ hingga $500 \mathrm{~cm}^{2}$ ), sehingga pengukuran tunggal mungkin tidak representatif [3]. Kerugian penggunaan penakar hujan manual, antara lain a) saat hujan lebat, kemungkinan air yang berada pada tabung meluap sehingga hasil pengukuran tidak memperlihatkan keadaan yang sebenarnya; b) intensitas (jumlah hujan per satuan waktu) tidak bisa didapat dengan merata-ratakan jumlah hujan dalam 1 hari atau 24 jam, karena pada umumnya hujan tidak turun terus-menerus selama 24 jam dan nilai kederasan/intensilas penuangan air yang berbeda memberi pengaruh yang berbeda pula. Sedangkan untuk pengadaan alat-alat ukur curah hujan yang bekerja secara otomatis diperlukan biaya yang cukup mahal. Kesalahan pengamat misalnya adanya data yang hilang dalam satu periode yang disebabkan oleh pengamatan yang tidak rutin, atau pembacaan skala yang dilakukan oleh beberapa pengamat yang mempunyai perbedaan dalam menginterpretasikan skala pembacaan [2].

Kinerja penakar hujan, khususnya sensor tipping bucket Rimco R/TBR-8, dilakukan di laboratorium dan di lapangan. Ada tiga hal yang disadari mengenai sensor tipping bucket, sensor tidak linier (artinya volume setiap ketukan air hujan sebanding dengan intensitas 
hujan), kesalahan ketukan ganda setelah beberapa ketukan tunggal (hal itu terjadi karena perbedaan antara volume siphon dengan volume wadah ketukan (bucket), yang juga dipengaruhi oleh intensitas hujan, sensitifitas ketidak linieran sensor dan ketukan berganda dengan pengaturan volume bucket. Hasil penelitian menyimpulkan bahwa tipping bucket dapat digunakan sebagai salah satu penakar hujan, karena bersifat nonlinier dan pengaturan volume siphon terhadap volume bucket karena merupakan fungsi intensitas hujan, data pengukuran curah hujan harus dikoreksi terhadap intensitas hujan yang sebenarnya [4]. Evaluasi kesalahan pengukuran penakar hujan tipping bucket sebesar 5-40\% lebih rendah dibandingkan nilai curah hujan yang sebenarnya. Nilai koreksi volumetri yang dapat menggantikan kesalahan sistematis akibat intensitas hujan. Percobaan dilakukan di laboratorium menggunakan tippng bucket dengan volume 3, 4, 5, 10, $20 \mathrm{~cm} 3$ dengan intensitas hujan buatan berkisar 8 sampai $500 \mathrm{~mm} / \mathrm{jam}$. Pengurangan kesalahan sebesar 5,2\%, 11,4\%, 17,7\%, 25,8\% and 37,7\% untuk intenstitas hujan masingmasing $50 \mathrm{~mm} / \mathrm{jam}, 100 \mathrm{~mm} / \mathrm{jam}, 200 \mathrm{~mm} / \mathrm{jam}, 300 \mathrm{~mm} / \mathrm{jam}$ dan $500 \mathrm{~mm} / \mathrm{jam}$ (dengan asumsi bahwa nominal volume tipping bucket $4 \mathrm{~cm} 3$ dan luas area penakar hujan $200 \mathrm{~cm}^{2}$ ) [5].

Untuk mengatasi kekurangan penakar hujan manual, penelitian menggunakan penakar hujan otomatis dilakukan secara global di dunia. Penakar hujan tipping bucket menjadi populer karena desainnya yang sederhana, tahan lama, dan murah; dan yang paling penting, kemampuan beradaptasi mereka untuk daerah-daerah terpencil. Alat pengukur curah ini dapat dengan mudah dipasang di daerah terpencil dan terhubung ke berbagai perangkat pemantauan [6]. Pengukur laju alir penakar hujan tipping bucket berukuran besar adalah instrumen yang sesuai diterapkan secara luas untuk mengukur aliran air dari parit atau lubang tanah yang digali di lereng bukit hutan. Alat ini lebih disukai untuk investigasi jangka pendek karena mobilitasnya, biaya lebih rendah, dan kemudahan pemasangan. Selain itu, kelebihan lain dengan resolusi temporal yang lebih tinggi, tanpa khawatir tentang aliran berlebihan yang dapat terjadi saat menggunakan kolektor [7].

Sebuah sistem yang ditujukan untuk mengenali secara otomatis sinyal curah hujan yang direkam dengan membalik penakar hujan tipping bucket dalam bagan strip kertas. Sistem ini terdiri dari tiga modul. Dua modul pertama secara otomatis mengekstraksi sinyal curah hujan dari gambar bagan strip digital: mereka tidak hanya didasarkan pada teknik analisis gambar, tetapi juga pada fitur mekanis dari instrumen rekaman dan pada pertimbangan yang timbul dari pemeriksaan bagan strip. Dengan demikian hasil sistem yang diusulkan jauh lebih kuat dan efisien daripada perangkat lunak tujuan umum yang dirancang untuk vektorialisasi gambar. Modul ketiga adalah antarmuka pengguna grafis yang memungkinkan verifikasi hasil yang diberikan oleh modul sebelumnya dan untuk secara interaktif mengubah bagian-bagian yang membutuhkan koreksi, jika ada. Sistem, yang berhasil diuji pada serangkaian besar bagan strip, merupakan alat yang sangat kuat untuk pemulihan otomatis data curah hujan kuno [8], mirip seperti penakar hujan Hellman, namun komponen kertas digantikan dengan strip digital. Desain dan konstruksi penakar hujan tipping bucket dari bahan plastik, juga dibuat. Beberapa unit dibuat dan diuji di lapangan dan di laboratorium. Dalam uji lapangan selama periode dua bulan, semua pengukur akurat hingga $\pm 2 \%$ dalam curah hujan, dalam kisaran 1-69 mm. Saat pengujian di laboratorium, penakar hujan hujan ini akurat dengan simulasi curah hujan hingga $180 \mathrm{~mm} /$ jam. Pengukur hujan murah untuk dibuat, ringan, tahan lama, dan cocok untuk lokasi terpencil. Keakuratan dan keandalannya membuatnya cocok untuk berbagai 
penggunaan lapangan. Alat penakar hujan komersial biasanya terlalu besar dan mahal. Keunggulan lain penakar hujan ini hampir seluruhnya terbuat dari bahan plastik, dipilih karena tahan terhadap kerusakan hewan di lapangan, mudah pembuatan, ekonomis, dan siap tersedia [9].

Pembuatan stasiun cuaca hemat biaya untuk sistem pemantauan. Stasiun cuaca ini menggunakan teknik komunikasi ZigBee. ZigBee digunakan melalui Bluetooth untuk jarak jangkauan pendek sekitar (1-10 m) dan lebih dari itu menggunakan Wi-Fi (jaringan area lokal nirkabel). Wi-Fi memiliki keterbatasan seperti penundaan (delay), kurang bisa melakukan transmisi data besar, dan beberapa daerah tidak memiliki jangkauan internet. Perangkat keras dan sensor digunakan untuk mengirim dan menerima data dalam sistem stasiun cuaca. Sistem ini menggunakan Arduino Uno dan lima sensor memberikan data bacaan keenam (keadaan hujan, tingkat angin, tekanan udara, kepadatan debu, suhu dan kelembaban). Data disimpan dalam kartu SD [10].

Alat ukur curah hujan untuk mengukur curah hujan harian dan intensitasnya dengan biaya pembuatan yang murah dan kemampuan yang memadai. Pada saaat pembuatan ada empat tahapan utama yang dilakukan adalah rancang bangun wadah (housing) penakar hujan, detector-transducer, perancangan piranti ukur elektronik dan kalibrasi. Prototipe alat ukur curah hujan hasil rancang bangun mempunyai kepekaan 0,51329 mm panjang/(mm curah hujan), ketidaktelitian 2,57493 mm-curah hujan; dan besar ketidaktepatan 2,59153 mm-curah hujan pada tingkat kepercayaan 95\% [2]. Penentukan besarnya persamaan matematika untuk mengoreksi penakar hujan tipping bucket besar secara umum, sehingga dapat mengurangi kesalahan pengukuran hingga 2-3\% [7].

Alat simulasi hujan untuk memahami proses hidrologi yang berpengaruh terhadap erosi di sistem drainasi perkotaan. Alat ini dibangun di daerah perkotaan yang hijau. Alat simulasi hujan ini berfungsi terbaik saat kecepatan angin calm. Hasil studi di lapangan menunjukkan bahwa ada korelasi yang baik antara curah hujan, erosi, infiltrasi, kandungan air tanah dan kemiringan permukaan [11]. Penakar hujan berbasis beban menggunakan sensor massa, sebagai wadah digunakan tabung dengan jari-jari $65 \mathrm{~mm}$. Air hujan akan ditimbang, untuk 1000 gram air, dengan luas lingkaran 13,27 mm², maka air itu mempunyai curah hujan $75,358 \mathrm{~mm}$. Setelah satu jam, ada motor DC yang akan membuang air hujan dari wadah/ember, sehingga intensitas hujan yang ditampilkan di layar LCD akan $\mathrm{mm} / \mathrm{jam}$. Proses mengolah data dari sensor berat ke layar LCD menggunakan mikrokontroler arduino uno dan konverter analog ke digital (ADC HX711) [12].

Penelitian mengenai perbandingan berbagai alat pengukur curah hujan juga telah dilakukan, Perbedaan rata-rata tahunan 6-tahun (1980-1985) dalam nilai-nilai curah hujan yang diukur menggunakan penakar hujan Hellmann dengan penakar hujan tipping bucket dengan lokasi yang sama di tempat terbuka di area bandara udara Jenewa sebesar $14 \%$. Penakar hujan tipping bucket menunjukkan lebih sedikit curah hujan. Perbedaan persentase dalam jumlah curah hujan harian tergantung pada kecepatan angin dan intensitas hujannya [13].

Karakteristik distribusi butiran hujan dan profil vertikal saat badai hujan parah 19-21 Juli 2016 di Beijing, Cina utara menggunakan dua disdrometer (OTT-Parsivel2 and 2DVideo-Distrometer) dan data penginderaan jarak jauh diamati menggunakan generasi kedua Micro Rain Radar (MRR2) [14] . Perbandingan tiga jenis penakar hujan, dengan cara melakukan Kalibrasi dinamis dan mengukur kesalahan. Tiga jenis penakar hujan, yaitu: HS-TB3 (Hydrological Services Pty Ltd.), ISCO674 (Isco, Inc.) dan TR-525 (Texas Electronics, 
Inc.) di laboratorium. Kisaran intensitas hujan yang diujikan adalah dari $5 \mathrm{~mm} / \mathrm{jam}$ sampai $250 \mathrm{~mm} /$ jam. Interval waktu pencatatan di data logger dari 1, 2, 5, 10 dan 20 menit. Hasil pengujian yang diperoleh semakin besar intensitas hujan semakin besar kesalahan pengukuran yang terjadi (lebih kecil dibandingkan nilai sebenarnya / underestimate), sehingga harus ada nilai koreksi yang diterapkan pada masing-masing penakar hujan. Urutan penakar hujan berasarkan tingkat kepercayaan dan konsisten pengukurannya pada kisaran intensitas hujan tertentu adalah HS-TB3 model, disusul dengan ISCO-674 dan yang terakhir TR-525 [6].

Institut Hidrologi dan Univeristas Teknik Hidrologi Graz di Austria mengoperasikan dua jaringan pemantauan hidrologi, yaitu di area sebelah timur Styria dan di kota Graz. Data hidrologi yang dikumpulkan adalah presipitasi, meteorologi dan aliran air permukaan. Hasil perbandingan penakar hujan hyetograf menunjukkan adanya penyimpangan antara intensitas hujan sebenarnya dengan intensitas hujan yang tercatat di penakar hujan [15]. Kalibrasi terhadap tujuh penakar hujan tipping bucket menggunakan peralatan kalibrasi yang dikembangkan pada pertengahan tahun 1990. Penakar hujan tersebut ditempatkan di area penelitian hidrologi di kota Grazk Austria. Proses kalibrasi menggunakan pompa peristaltik. Beberapa penakar hujan menunjukkan penyimpangan positif tidak lebih besar daripada $22 \%$ pada intensitas hujan dibawah 0,5 $\mathrm{mm} / \mathrm{menit}$, hal itu terjadi karena adanya air yang tertinggal di bucket saat diantara ketukan. Sedangkan penyimpangan / deviasi negatif terjadi karena adanya air yang hilang saat terjadi ketukan. Hal itu membuat nilai yang tercatat lebih kecil daripada nilai intensitas hujan sebenarnya. Penyimpangan lebih kecil daripada nilai sebenarnya bisa melebihi persentasi 30\%. Volume tipping bucket yang besar $\left(5 \mathrm{~cm}^{3}\right)$ menunjukkan deviasi yang lebih rendah daripada volume tipping bucket yang kecil $\left(2 \mathrm{~cm}^{3}\right)$. Hasil penelitian ini menyarankan agar penakar hujan dikalibrasi minimal 2-3 tahun sekali [16]. Kalibrasi penakar hujan, antara penakar hujan tipping bucket dengan penakar hujan Hellman. Hasil penelitian menunjukkan ada perbedaan antara intenstas hujan yang terukur dan dihitung oleh kedua penakar hujan. Penelitian ini menunjukkan bahwa ukuran siphon (jalan masuk dari corong ke bucket) mempengaruhi akurasi dan kuantitas air hujan, dengan adanya ketukan yang tidak teratur "false double tips" [17]. Perbandingan antara hasil penakar hujan tipping bucket dengan penakar hujan drop counter (penghitung tetesan hujan) untuk mencari algoritma nilai koreksi. Sebagai acuan di lapangan digunakan data resolusi 1 menit penakar hujan drop counter dengan intensitas rendah sampai sedang. Penyimpangan yang terukur terutama akibat kesalahan sampling pada resolusi rendah tipping bucketnya $(0,5 \mathrm{~mm})$. Ada dua metode atau algoritma koreksi yang dilakukan, yaitu mendistribusikan volume air hujan pada setiap antara ketukan dan kedua melakukan memperindah/mempercantik (smoothing) volume awal, volume terisolasi dan volume akhir sesuai dengan klimatologi (intensitas hujannya) [18].

Perbandingan data antara penakar hujan tipping bucket dengan penakar hujan timbangan elektronik untuk hujan salju. Periode perbandingan dilakukan selama 173 hari di musim dingin 2009 dan 2010, lokasi perbandingan dilakukan di stasiun cuaca Zermatt di Pegunungan Alpen, Swiss dengan ketinggian 1638 meter di atas permukaan laut. Kelebihan penakar hujan timbangan elektronik adalah sedikitnya kehilangan curah hujan karena penguapan dan akurasi yang lebih tinggi saat menentukan awal terjadinya hujan. Kelemahan penakar hujan tipping bucket adalah hilangnya 23,7\% total curah hujan karena dilengkapi alat ini dilengkapi pemanas dan adanya kemunduran waktu 30 menit saat awal kejadian hujan [19]. 
Perbandingan tiga penakar hujan juga dilakukan di di Stasiun lysimeter Marienfede di Berlin, Jerman, dari 20 Juli 2012 sampai 11 september 2013. Penakar hujan yang dibandingkan adalah penakar hujan Hellman, penakar hujan otomatis dan sebagai nilai referensinya adalah lysimeter. Presipitasi dalam bentuk air hujan, salju dan embun diukur menggunakan 3 buah penakar hujan Hellman dengan luasan $100 \mathrm{~cm}^{2}$ dan tinggi $33 \mathrm{~cm}$ (yang dikosongkan isinya seminggu sekali), 3 buah lysimeter dan 1 buah penakar hujan tipping bucket otomatis. Hasil kumulatif curah hujan dengan lysimeter terukur dengan kisaran 661 sampai $667 \mathrm{~mm}$ (rata-rata $664 \mathrm{~mm}$ ), dengan penakar hujan Hellman terukur dengan kisaran 651 sampai $669 \mathrm{~mm}$ (rata-rata $659 \mathrm{~mm}$ ), dan penakar hujan otomatis 580 $\mathrm{mm}$. Berarti dibandingkan dengan lysimeter, penakar hujan Hellman mengukur 0,7\% lebih rendah, dan penakar hujan otomatis mengukur 12,7\% lebih kecil. Hasil analisa menunjukkan pengukuran curah hujan menggunakan lysimeter disertai dengan penyortian data menunjukkan nilai akurasi data tertinggi dan dapat menghindari dari sistematis error (gangguan angin dan hilangnya curah hujan karena penguapan). Penakar hujan Hellman berukuran kecil ditempatkan di atas tanah mempunyai data yang dapat dibandingkan dengan data lysimeter [1].

Pengumpulan data dalam bentuk netcdf, data curah hujan dan data partikel, ukuran dan kecepatan tetesan air hujan, yang diukur di Observatorium Huancayo, Pegunungan Tropis Andes, Peru. Data curah hujan berasal dari disdrometer Parsivel2 dan penakar hujan tipping bucket. Data ini kemudian dapat dipergunakan untuk mempelajari mikrofisis hujan orografik, model atmosfer dan algorima perkiraan curah hujan [20].

Data kekeringan dari sensor tanah dengan data kekeringan dari model WAVE3.0. Data kekeringan ini digunakan untuk mengaktifkan sensor hujan untuk melakukan irigasi / penyiraman saat terjadinya kekeringan di tanah. Sebagai data input model Wave 3.0 adalah data perjam meteorologi, ketinggian anemometer, temperatur udara dan kelembaban udara untuk menghitung nilai evapotranspirasi. Ada tiga jenis tanah yang diteliti yaitu, pasir, lempung dan tanah humus. Hasil penelitian menunjukkan adanya perbedaan data waktu kering tanah antara model dengan kenyataan sensor tanah untuk pasir, lempung humus dan tanah lempung masing-masing 52, 75 dan 89 jam [21]. Perbandingan antara data radar cuaca yang telah di kalibrasi dengan 12 penakar hujan tipping bucket untuk melakukan estimasi kejadian erosi. Hasil penelitian ini menunjukkan data radar cuaca dapat digunakan untuk menunjukkan waktu kejadian erosi dan sebagai informasi manajemen kejadian kebakaran hutan dan pengaturan tindakan terhadap erosi [22].

Perbandingan data hujan yang diperoleh dari disdrometer RD-69 tipe Joss-Waldvogel dan penakar hujan tipping bucket 0,2 $\mathrm{mm}$ tipe RW Munro. Lokasi penelitian dilakukan di Chilbolton daerah Inggris selatan. Periode data yang dibandingkan dari 2007 sampai 2009. Data intensitas curah hujan kemudian disimulasikan menggunakan tiga model: Artificial Neural Network (ANN), Cubic Spline Algorithm (CSA), Multiple Linear Regression method (MLR). Kinerja perbandingan intensitas hujan antara disdrometer dan penakar hujan tipping bucket digunakan Nash-Sutcliffe Efficiency (NSE) dan Root Mean Square Error (RMSE). NSE dalam unit tanpa satuan, RMSE dalam $\mathrm{mm} / \mathrm{jam}$. Hasil analisis menunjukkan MLR yang terbaik untuk memperkirakan intensitas hujan dengan NSE 0,841 dan RMSE terendahnya 2,212. Kebalikannya ANN memiliki NSE 0,1 lebih rendah dan RMSE 0,5 lebih besar daripada CSA [23].

Alat pengukur curah hujan otomatis di Indonesia secara komersial berharga mahal sehingga hanya lembaga pemerintah, swasta dan beberapa lembaga pendidikan yang 
mengoperasikan peralatan ini. Pembuatan prototype alat pengukur curah hujan menggunakan rancangan sendiri dengan harga biaya komponen yang lebih murah, menggunakan sensor sederhana dengan rangkaian elektronika yang sederhana, diharapkan dapat dijadikan alternatif untuk operasional penakar hujan.

Prinsip kerja dari alat ini mirip seperti alat ukur curah hujan tipping bucket di mana saat air hujan sudah mencapai volume tertentu, air hujan akan dibuang dan didapatkan data waktu yang dibutuhkan untuk mencapai volume tersebut. Sensor yang digunakan pada alat yang dibuat bukan reed switch seperti yang digunakan pada alat ukur curah hujan tipping bucket, namun menggunakan sensor beban (Load Cell). Karena keluaran dari sensor Load Cell bukanlah data curah hujan, dibutuhkan sesuatu yang dapat mengubah data yang didapatkan dari sensor ke data curah hujan. Oleh karena itu, digunakan Arduino Uno dan MATLAB.

\section{Metodologi Penelitian}

Bahan-bahan dan peralatan yang digunakan pada penelitian ini:

- Multimeter,

- Akuades dalam botol mewakili air hujan,

- Gelas Ukur $10 \mathrm{~mL}$ dan $500 \mathrm{~mL}$,

- Timbangan Digital,

- Laptop yang sudah diinstal aplikasi Arduino IDE dan Matlab

- Arduino UNO,

- Sensor Load Cell,

- ADC HX711 24 bit,

- Kabel Jumper,

- Gergaji Mesin,

- Palu,

- Meteran,

- LAS,

- Bor Listrik,

- Kuas Cat 1 inci

Pekerjaan pembuatan penakar hujan, perakitan elektronika, pengujian penakar hujan dilakukan di Bengkel Fisika, Jurusan Pendidikan Fisika, Universitas Negeri Yogyakarta. Daerah Istimewa Yogyakarta. Pembuatan program Arduino Uno dan Script Matlab dilakukan di Stasiun Klimatologi Klas IV Sleman.

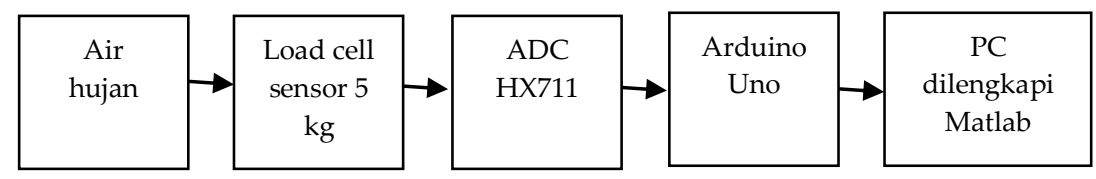

Gambar 1. Skematik lengkap dari sistem

Gambar skematik penakar hujan disajikan dalam Gambar 1. Cara kerja penakar hujan ini adalah mirip seperti "Ember Tumpah" di mana ember akan berputar saat massa air di 
bagian atas tumpuan lebih besar dari bagian bawah tumpuannya seperti ditunjukkan Gambar 2.

Rancang bangun prototipe alat ukur curah hujan elektronik terdiri atas tiga bagian, yaitu rumah ukur dan corong penangkap hujan detektor-tranduser, dan piranti elektronik. Untuk mengetahui unjuk kerja alat hasil rancang bangun tersebut. maka dua hal yang harus dilakukan yaitu kalibrasi dan pengujian di lapangan. Rancang bangun alat ukur curah hujan dengan konstruksi cantilever (tipping bucket) pada dasarnya sama dengan alat ukur curah hujan tipe timbangan, hanya saja pada alat ukur curah hujan tipe timbangan digunakan pegas, sedangkan pada alat ukur curah hujan dengan konstruksi cantilever digunakan batang. Di mana ujung yang satu dijepit, sedangkan ujung lainnya dalam keadaan bebas; dan air yang tertampung pada silinder penampung ditempatkan pada ujung bebas tersebut [2].

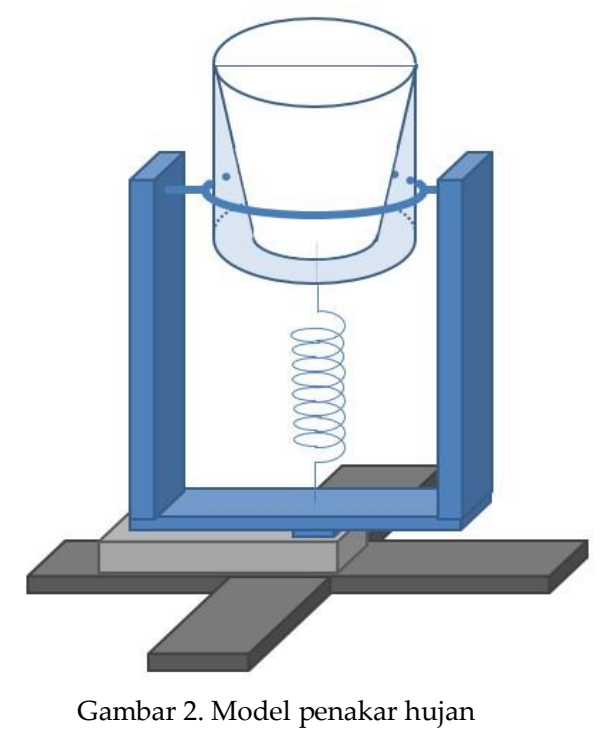

Pada penelitian ini alat ukur curah hujan yang dibuat menggunakan sistem timbangan. Sensor yang digunakan adalah sensor massa (load cell). Alat ukur ini merupakan alat ukur curah hujan dengan pengukuran langsung pada massa air hujan yang didapat. Alat ukur curah hujan ini terhubung dengan mikrokontroller Arduino Uno untuk mengirimkan data hasil pemindaian sensor massa (load cell) ke mikrokontroller Arduino Uno. Sensor load cell dilengkapi dengan modul amplifier HX711 untuk menguatkan sinyal dan mengkonversikan data analog hasil pengukuran load cell untuk diproses oleh Arduino Uno lalu ditampilkan dengan MATLAB berupa grafik real-time.

Saat manufaktur alat sudah selesai, dilakukan tahapan berikut ini untuk mendapatkan data curah hujan berdasarkan keluaran sensor Load Cell :

- Perancangan bagian elektronika

- Pembuatan Program pada Arduino Uno

- Pembuatan Program pada MATLAB

- Mengamati Keluaran Data Curah Hujan 


\section{Hasil Dan Pembahasan}

Penakar hujan yang telah dibuat ditunjukkan oleh Gambar 3.

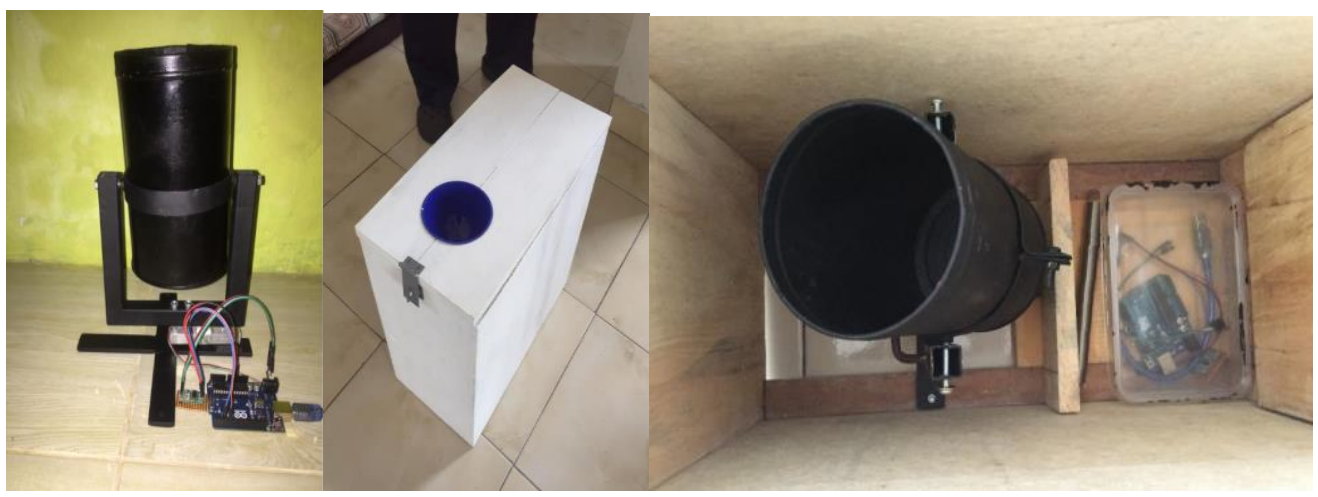

(a)

(b)

(c)

Gambar 3. Penakar hujan yang dibuat (a), tampak dari luar setelah di beri housing (b), tampak dari atas di dalam housing (c)

\subsection{Analisis Bentuk Wadah}

Container/wadah alat ukur ini terdiri dari dua bagian yaitu bagian dalam dan bagian luar, untuk bagian luar berbentuk tabung dan untuk bagian dalam adalah berbentuk limas segiempat yang ujungnya dipotong. Volume yang diperlukan untuk analisis adalah volume dari wadah bagian dalam, yaitu limas yang ujungnya dipotong. Akan tetapi untuk mengetahui luas alas limas segiempat tersebut harus tetap memperhatikan luas alas dari tabungnya karena jika terlalu besar pasti tidak bisa masuk dan jika terlalu kecil akan ada kemungkinan wadah mengalami kebocoran. Bagian dalam wadah akan berbentuk seperti limas segiempat yang dipotong atasnya, hal ini di maksudkan untuk memudahkan air yang akan mengalir keluar dari wadah saat alat sedang berputar karena limas memiliki sudut pada tiap sisinya dan dibantu juga dengan bentuk limas yang semakin mengkerucut untuk mempermudah air mengalir.

\subsection{Sensor Beban (Load Cell)}

Sensor Beban (load cell) adalah sensor untuk menghitung massa pada suatu benda dengan menggunakan prinsip kerja jembatan wheatstone di dalamnya. Sensor load cell ini memiliki tegangan keluaran dalam orde $\mathrm{mV}$ yang terbaca terhadap perubahan nilai resistansi yang dapat mengartikan massa benda tersebut. Sensor ini memiliki transduser yang mengukur ketegangan kawat, di mana mengubah tegangan mekanis menjadi sinyal listrik. Dasar penginderaannya perubahan tahanan pengantar (transduser) yang berubah akibat perubahan panjang dan luas penampangnya. Load cell merupakan sensor timbangan yang bekerja secara mekanis, di mana load cell menggunakan prinsip tekanan yang memanfaatkan strain gauge sebagai pengindera (sensor). Strain gauge adalah sebuah transduser pasif yang merubah suatu pergeseran mekanis menjadi perubahan tahanan. Perubahan ini kemudian diukur dengan jembatan Wheatsone di mana tegangan keluaran dijadikan referensi beban yang diterima load cell. 


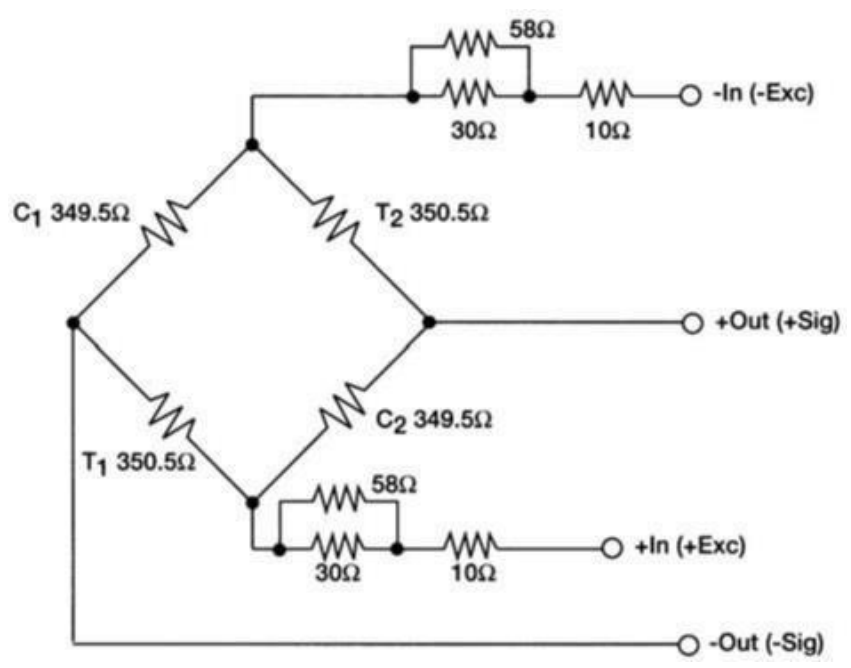

Gambar 4. Rangkaian elektronika dalam sensor load cell

Prinsip kerja dari load cell adalah menggunakan Strain Gauge yang tersusun dari kawat sangat halus, yang dianyam secara berulang menyerupai kotak dan ditempelkan pada plastik atau kertas sebagai medianya. Kawat yang dipakai dari jenis tembaga lapis nikel berdiameter sekitar seper seribu $(0,001)$ inchi. Kawat itu disusun bolak-balik untuk mengefektifkan panjang kawat sebagai fraksi terhadap tekanan/gaya yang mengenainya. Pada ujungnya dipasang terminal. Strain Gauge bisa dibuat sangat kecil, sampai ukuran 1/64 inchi. Untuk membuat Load Cell, Strain Gauge dilekatkan pada logam yang kuat sebagai bagian dari penerima beban (load receptor). Strain Gauge ini disusun sedemikian rupa membentuk Jembatan Wheatstone, seperti ditunjukkan oleh Gambar 4.

\subsection{Analog to Digital Converter (ADC) HX711}

Modul Amplifier Analog to Digital Converter HX711 adalah modul yang menguatkan dan mengubah sinyal analog yang didapat dari sensor load cell menjadi sinyal digital. Caranya yaitu menghubungkan modul amplifier HX711 dengan mikrokontroler Arduino Uno, lalu kita dapat melihat perubahan nilai resistansi pada sensor load cell tersebut, seperti ditunjukkan Gambar 5.

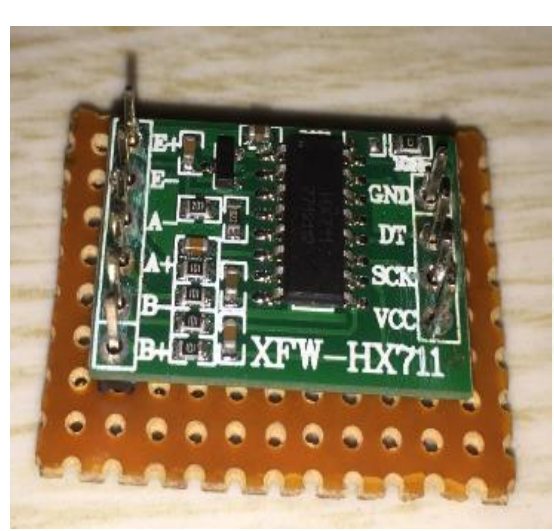

(a)

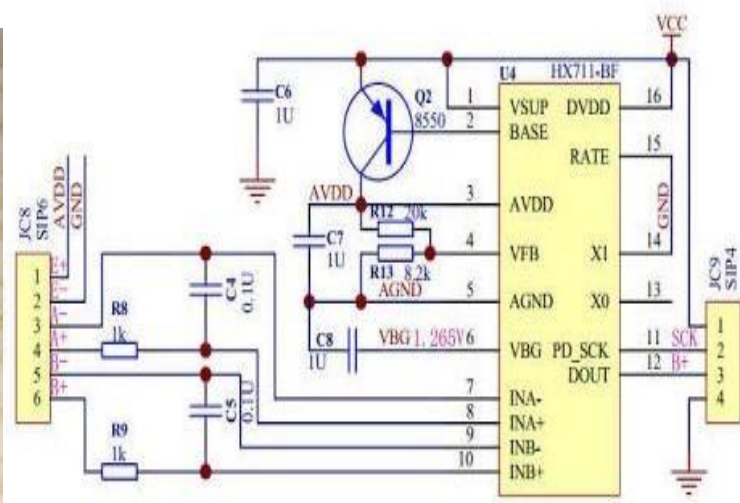

(b)

Gambar 5. Modul ADC HX711 (a), Rangkaian elektronika dalam Modul ADC HX711 24 bit (b) 
IC HX711 adalah IC ADC 24 bit dengan output serial digital IC ini merupakan Modul pengkondisi sinyal untuk load cell, dan keluaran IC ini berupa tegangan yang sebanding dengan berat yang diberikan. Dalam proses pengambilan data diperlukan 2 tahap untuk mendapat data yang akurat karena input dan output tdk 100\% linier maka perlu dicari persamaan untuk linierisasi hubungan input vs output terlebih dahulu. Untuk persamaan linearisasi-nya menggunakan persamaan

$$
y=m x+c
$$

di mana,

$$
\begin{array}{ll}
y & =\text { output ADC, } \\
m & =\text { gradient/kemiringan, } \\
x & =\text { berat beban, } \\
c & =\text { konstanta/offset. }
\end{array}
$$

\subsection{Arduino Uno}

Bahasa pemograman Arduino menggunakan Bahasa Pemograman C yang sudah dimodifikasi khusus untuk Arduino agar para user dari tingkat pemula sampai mahir dapat menggunakannya. Modul Arduino Uno yang digunakan ditunjukkan oleh Gambar 6.

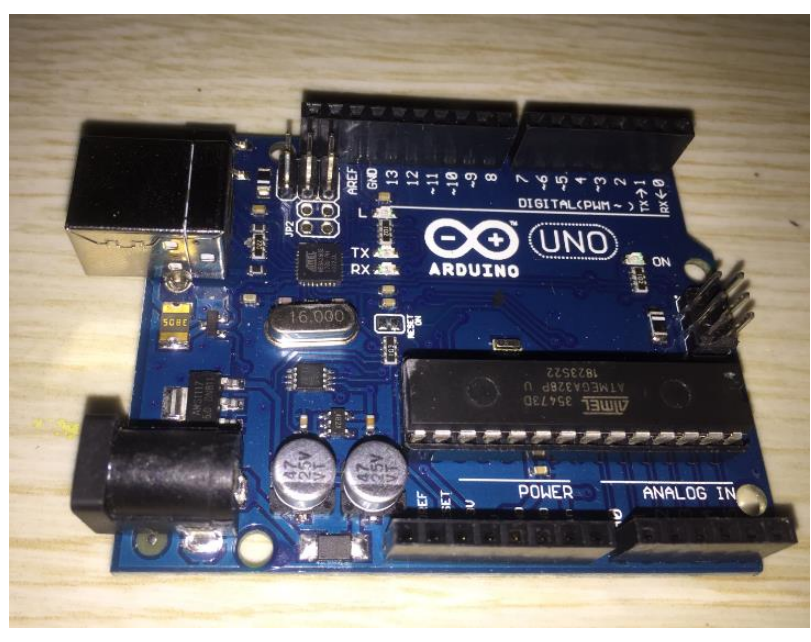

Gambar 6. Modul Arduino Uno

Bahasa pemograman Arduino menggunakan Bahasa Pemograman C yang sudah dimodifikasi khusus untuk Arduino agar para user dari tingkat pemula sampai mahir dapat menggunakannya. Kelebihan lain dari bahasa pemograman Arduino adalah lebih mudah untuk dipelajari. Gambar 7 menunjukkan flowchart pada Arduino Uno untuk mengubah keluaran dari sensor Load Cell yaitu data berat, menjadi data curah hujan. 


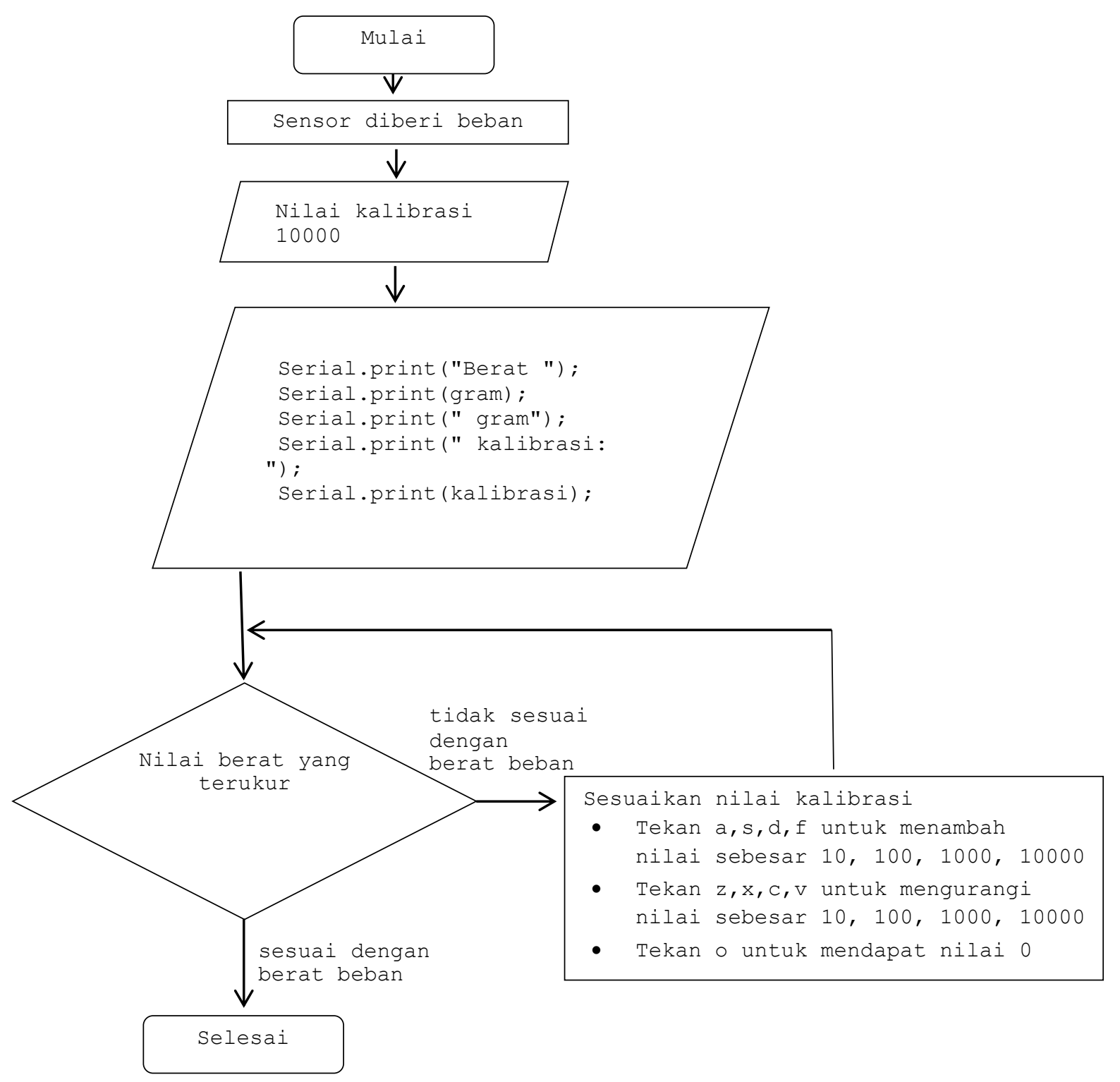

Gambar 7. Flowchart mengambil data curah hujan

Pada bagian ini, dilakukan kalibrasi terhadap data yang didapatkan dari sensor Load Cell. Kalibrasi ini bertujuan untuk menyamakan berat yang terukur pada timbangan dengan berat yang terukur pada sensor Load Cell. Setelah dikalibrasi, dilakukan pengubahan data ke data curah hujan. Gambar 8 menunjukkan flowchart pengubahan data ke data curah hujan. 


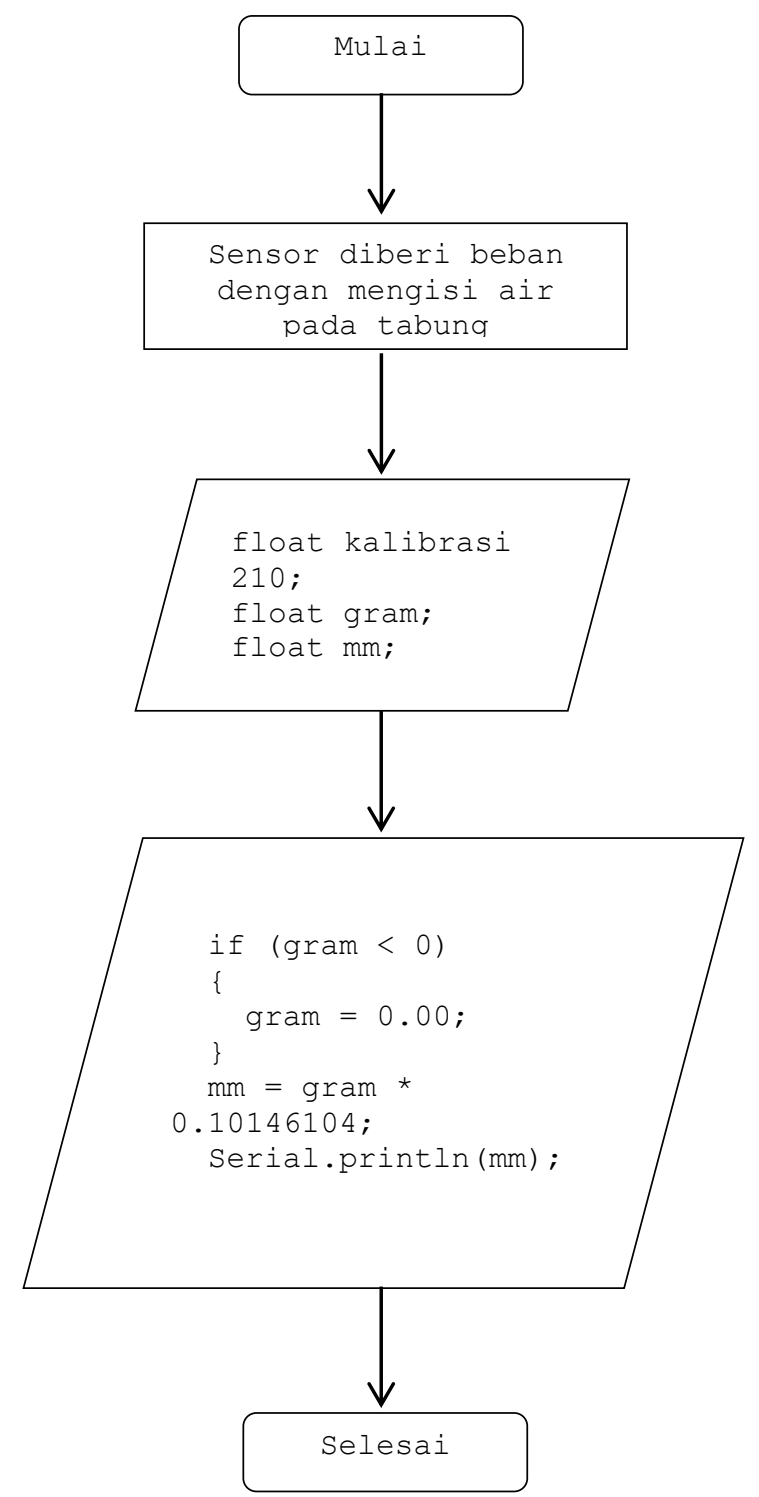

Gambar 8. Flowchart konversi ke nilai curah hujan

Berdasarkan kalibrasi yang dilakukan, didapat nilai kalibrasinya ialah 210. Kemudian untuk mendapatkan data curah hujan yang memiliki satuan milimeter, hasil pengukuran dari sensor Load Cell dengan satuan gram diubah ke satuan $\mathrm{mm}^{3}$ dan dibagi dengan luas alas alat yang menampung air hujan. Sehingga didapatkan data curah hujan. Data curah hujan ini dapat dilihat langsung pada aplikasi arduino.

\subsection{Program MATLAB R2013a}

Data yang ditampilkan berupa data curah hujan tiap waktu delay yang ditetapkan. Untuk mendapatkan data antara waktu dan curah hujan, digunakan aplikasi MATLAB. Gambar 9 menunjukkan flowchart pada Matlab yang digunakan. 


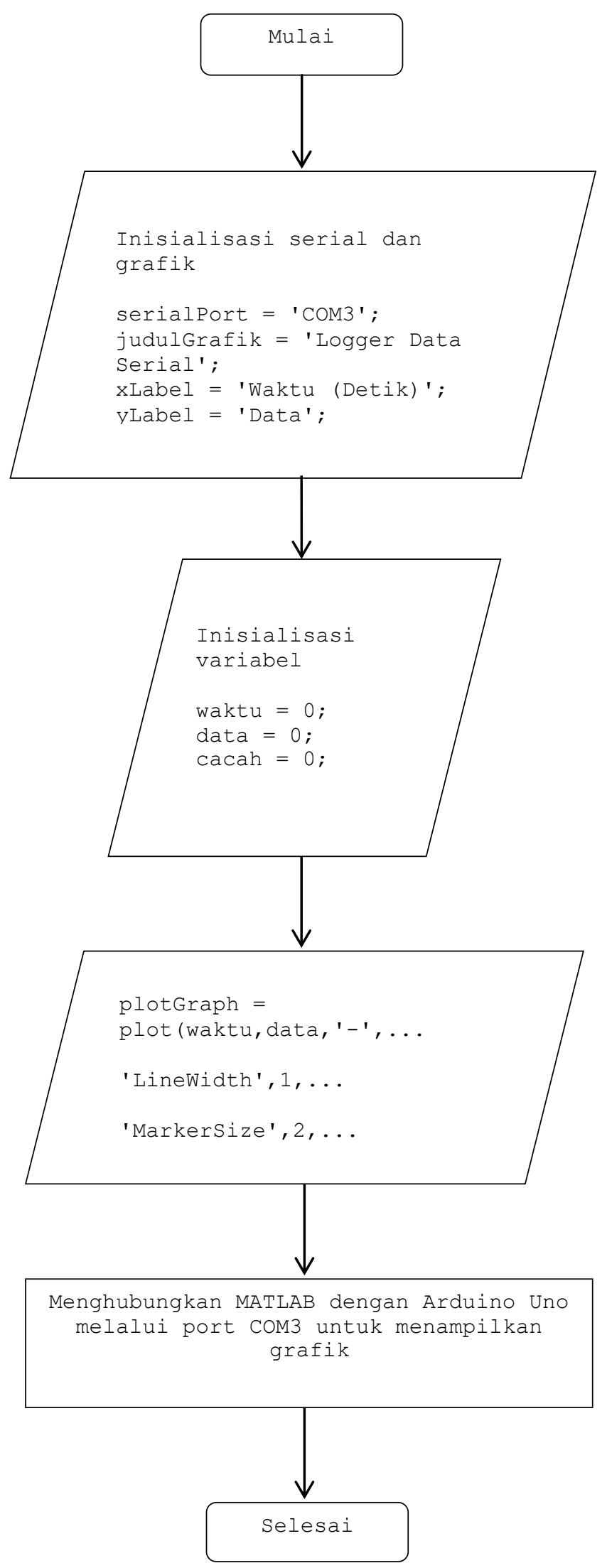

Gambar 9. Flowchart pada Matlab 
Pembuatan Penakar Hujan Berbiaya Rendah Menggunakan Sensor Beban Berbasis

Arduino Uno

Agusta Kurniawan, Indah Mulia, Sabella Nisa Adelia Rifai , Sigit Purwandika

\subsection{Hasil Pengujian}

Tabel 1. Hubungan antara tegangan keluaran dengan volume

\begin{tabular}{|c|c|c|}
\hline No & Tegangan Keluaran $(\mathrm{mV})$ & Volume $(\mathrm{mL})$ \\
\hline 1. & 0,8 & 0 \\
\hline 2. & 0,9 & 30 \\
\hline 3. & 1 & 180 \\
\hline 4. & 1,1 & 300 \\
\hline 5. & 1,2 & 450 \\
\hline 6. & 1,3 & 550 \\
\hline
\end{tabular}

Alat ukur ini belum diuji untuk pengambilan data curah hujan di lapangan namun sudah melakukan pengambilan data hubungan antara tegangan dengan volume. Hal ini dilakukan untuk mengkonversi nilai tegangan menjadi nilai volume yang nantinya nilai volume tersebut akan dikonversi kembali menjadi nilai curah hujan dalam bentuk satuan $\mathrm{mm}$. Pengujian ini dilakukan dengan cara menuangkan air pada volume per $10 \mathrm{~mL}$ lalu akan terbaca tegangan signifikan pada multimeter, sesuai dengan Tabel 1.

Setelah mengetahui data tersebut selanjutnya adalah melakukan pengujian, dengan cara membandingkan massa keluaran alat ukur curah hujan yang telah dibuat dengan neraca digital. Hasil didapatkan dari Gambar 10 menunjukkan masih ada perbedaan massa antara keluaran alat ukur penakar hujan dengan massa di neraca digital pada berbagai variasi curah hujan dari $1 \mathrm{~mm}$ hingga $100 \mathrm{~mm}$. Massa air hujan terbaca sama saat curah hujan $54 \mathrm{~mm}$, yaitu sama-sama 105 gram, baik pada neraca digital maupun respon pada sensor load cell. Saat curah hujan di bawah $54 \mathrm{~mm}$, massa neraca digital lebih besar daripada massa respon pada sensor load cell, kebalikannya saat curah hujan di atas $54 \mathrm{~mm}$, massa neraca digital lebih kecil daripada massa respon pada sensor load cell.

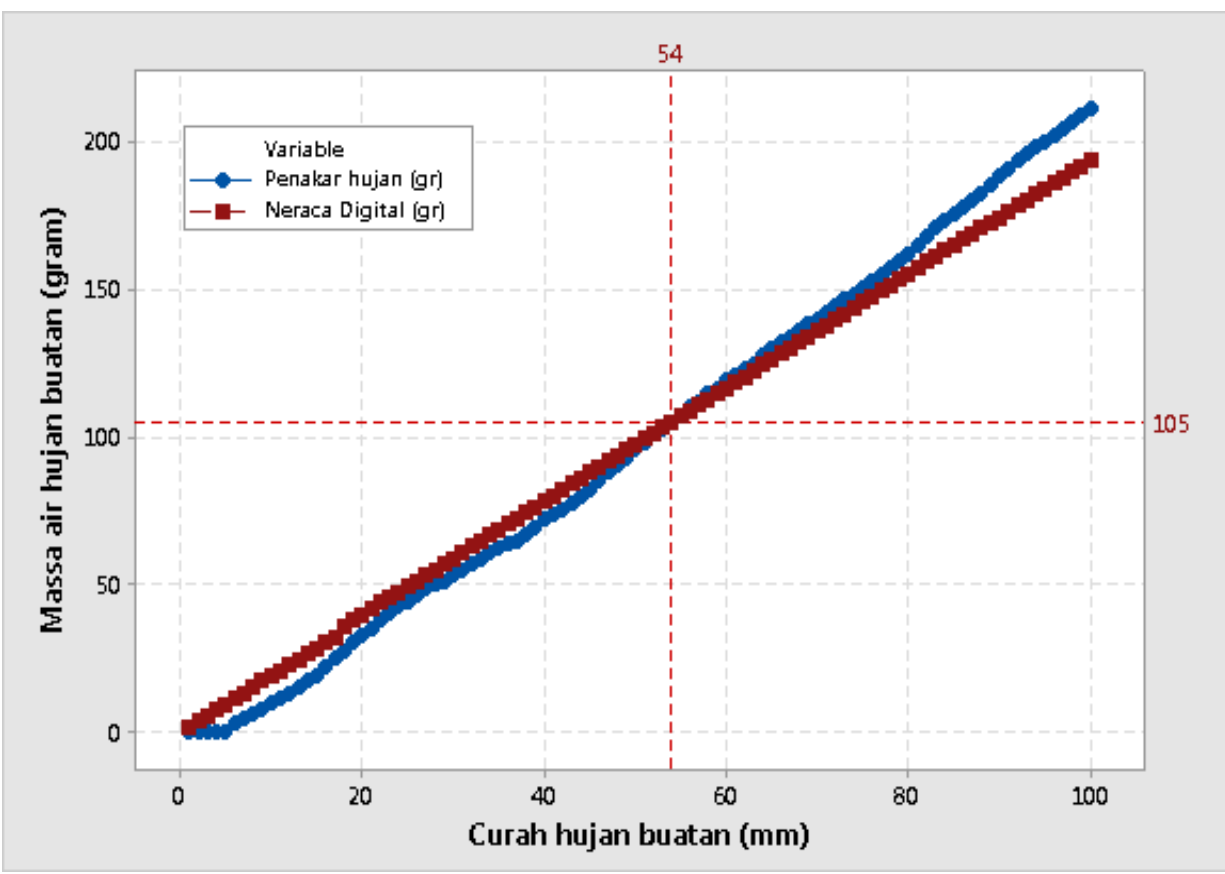

Gambar 10. Perbedaan massa antara keluaran alat ukur penakar hujan dengan massa di neraca digital pada berbagai variasi curah hujan dari $1 \mathrm{~mm}$ hingga $100 \mathrm{~mm}$ 


\section{Kesimpulan}

Penelitian ini menghasilkan alat ukur curah hujan dengan sistem timbangan menggunakan sensor load cell sebagai komponen sensornya. Dari pengujian-pengujian yang telah dilakukan, terlihat bahwa alat ukur curah hujan ini dapat berfungsi dengan baik, namun masih memerlukan perbaikan dan pengaturan lebih lanjut untuk kegiatan operasinal sehari-hari.

\section{Ucapan Terimakasih}

Penulis mengucapkan terima kasih kepada pimpinan Stasiun Klimatologi Kelas IV Sleman, yang telah memberikan izin penelitian dalam bentuk Kerja Magang Mahasiswa. Selain itu penulis juga mengucapkan terima kasih kepada segenap pimpinan Program Studi Fisika, Jurusan Pendidikan Fisika dan Fakultas MIPA, Universitas Negeri Yogyakarta atas semua izin dan perlengkapan penelitian ini. Tak lupa penulis mengucapkan terima kasih kepada redaktur, editor dan mitra bestari jurnal Techné.

\section{Daftar Pustaka}

[1] M. Hoffmann, R. Schwartengräber, G. Wessolek, and A. Peters, "Comparison of simple rain gauge measurements with precision lysimeter data," Atmos. Res., vol. 174175, pp. 120-123, 2016, doi: 10.1016/j.atmosres.2016.01.016.

[2] Winarto, R. Handoyo, and B. H. Priyambodo, "Rancang Bangun Alat Ukur Curah Hujan Elektronik," Agritech, vol. 11, no. 3, pp. 31-40, 2007, doi: 10.22146/agritech.19225.

[3] WMO, Guide to meteorological instruments and methods of observation, 7th ed., vol. 8. Geneva, Switzerland: World Meteorological Organization, 2008.

[4] Č. Maksimović, L. Bužek, and J. Petrović, "Corrections of rainfall data obtained by tipping bucket rain gauge," Atmos. Res., vol. 27, no. 1-3, pp. 45-53, 1991, doi: 10.1016/0169-8095(91)90005-H.

[5] P. Sypka, "Dynamic real-time volumetric correction for tipping-bucket rain gauges," Agric. For. Meteorol., vol. 271, no. February, pp. 158-167, 2019, doi: 10.1016/j.agrformet.2019.02.044.

[6] V. S. Shedekar, K. W. King, N. R. Fausey, A. B. O. Soboyejo, R. D. Harmel, and L. C. Brown, "Assessment of measurement errors and dynamic calibration methods for three different tipping bucket rain gauges," Atmos. Res., vol. 178-179, pp. 445-458, 2016, doi: 10.1016/j.atmosres.2016.04.016.

[7] T. Shimizu, M. Kobayashi, S. Iida, and D. F. Levia, "A generalized correction equation for large tipping-bucket flow meters for use in hydrological applications," J. Hydrol., vol. 563, no. June, pp. 1051-1056, 2018, doi: 10.1016/j.jhydrol.2018.06.036.

[8] R. Deidda, G. Mascaro, E. Piga, and G. Querzoli, "An automatic system for rainfall signal recognition from tipping bucket gage strip charts," J. Hydrol., vol. 333, no. 2-4, pp. 400-412, 2007, doi: 10.1016/j.jhydrol.2006.09.011.

[9] K. A. Cornish and G. C. Green, "An economical recording tipping-bucket rain gauge," Agric. Meteorol., vol. 26, no. 4, pp. 247-253, 1982, doi: 10.1016/0002-1571(82)90041-3.

[10]Z. K. Hussein, H. J. Hadi, M. R. Abdul-Mutaleb, and Y. S. Mezaal, "Low cost smart weather station using Arduino and ZigBee," Telkomnika (Telecommunication Comput. 
Electron. Control., vol. 18, no. 1, pp. 282-288, 2020, doi: 10.12928/TELKOMNIKA.v18i1.12784.

[11]K. T. Nielsen et al., "Automated rainfall simulator for variable rainfall on urban green areas," Hydrol. Process., vol. 33, no. 26, pp. 3364-3377, 2019, doi: 10.1002/hyp.13563.

[12]A. D. Ibrahim, H. Basarudin, A. F. Ramli, M. Yaakop, M. I. Sulaiman, and M. A. Abu, "Development of rain gauge using weight measurement for microwave network," AIP Conf. Proc., vol. 2129, no. July, 2019, doi: 10.1063/1.5118134.

[13]B. Sevruk, "Adjustment of tipping-bucket precipitation gauge measurements," Atmos. Res., vol. 42, no. 1-4, pp. 237-246, 1996, doi: 10.1016/0169-8095(95)00066-6.

[14]L. Luo et al., "Raindrop size distribution and microphysical characteristics of a great rainstorm in 2016 in Beijing, China," Atmos. Res., vol. 239, no. June 2019, p. 104895, 2020, doi: 10.1016/j.atmosres.2020.104895.

[15]H. Bergmann, H. Breinhälter, O. Hable, and R. Krainer, "Calibration of tipping bucket hyetographs," Phys. Chem. Earth, Part C Solar, Terr. Planet. Sci., vol. 26, no. 10-12, pp. 731-736, 2001, doi: 10.1016/S1464-1917(01)95017-2.

[16]V. Vasvári, "Calibration of tipping bucket rain gauges in the Graz urban research area," Atmos. Res., vol. 77, no. 1-4 SPEC. ISS., pp. 18-28, 2005, doi: 10.1016/j.atmosres.2004.12.012.

[17]S. Overgaard, A. H. El-Shaarawi, and K. Arnbjerg-Nielsen, "Calibration of tipping bucket rain gauges," Water Sci. Technol., vol. 37, no. 11, pp. 139-145, 1998, doi: 10.2166/wst.1998.0454.

[18]M. Colli, L. G. Lanza, and P. W. Chan, “Co-located tipping-bucket and optical drop counter RI measurements and a simulated correction algorithm," Atmos. Res., vol. 119, pp. 3-12, 2013, doi: 10.1016/j.atmosres.2011.07.018.

[19]M. Savina, B. Schäppi, P. Molnar, P. Burlando, and B. Sevruk, "Comparison of a tipping-bucket and electronic weighing precipitation gage for snowfall," Rainfall Urban Context Forecast. Risk Clim. Chang., vol. 103, pp. 45-51, 2012, doi: 10.1016/j.atmosres.2011.06.010.

[20]J. M. Valdivia, K. Contreras, D. Martinez-Castro, E. Villalobos-Puma, L. F. SuarezSalas, and Y. Silva, "Dataset on raindrop size distribution, raindrop fall velocity and precipitation data measured by disdrometers and rain gauges over Peruvian central Andes (12.0S)," Data Br., vol. 29, p. 105215, 2020, doi: 10.1016/j.dib.2020.105215.

[21]B. Cardenas and M. D. Dukes, "Dry-Out Periods of Rain Sensors vs. Soil Dry-Out: Water Saving Potential and Recommendations," Vadose Zo. J., vol. 17, no. 1, p. 170185, 2018, doi: 10.2136/vzj2017.10.0185.

[22]Q. Zhu et al., "Estimation of event-based rainfall erosivity from radar after wildfire," L. Degrad. Dev., vol. 30, no. 1, pp. 33-48, 2019, doi: 10.1002/ldr.3146.

[23]J.-O. Park, S. Yoon, M. H. Na, and H.-C. Song, "The Effects of Air Pollution on Mortality in South Korea," Procedia Environ. Sci., vol. 26, pp. 62-65, 2015, doi: 10.1016/j.proenv.2015.05.025. 
